\title{
Photosynthetic activity of young Ricinus communis L. plants under conditions of flooded soil
}

\author{
Atividade fotossintética de plantas jovens de Ricinus communis $\mathbf{L}$. \\ sob alagamento do solo
}

\author{
Davi Silva Dalberto ${ }^{1 *}$; Emanuela Garbin Martinazzo ${ }^{2}$; Cristina Moll Hüther ${ }^{3}$; \\ Douglas Antônio Posso ${ }^{4}$; Marcos Antonio Bacarin ${ }^{5}$
}

\begin{abstract}
Soil flooding is a stress condition that causes changes in hydric relationships and in the metabolism of crops, thereby affecting their productivity. To evaluate the effects of soil flooding on the chlorophyll $a$ fluorescence transient, as well as gas exchange and Ricinus communis growth, young plants of the 'AL Guarany 2002' and 'IAC Guarani' cultivars, grown in a greenhouse, were subjected to flood conditions by maintaining a layer of water $2-3 \mathrm{~cm}$ above the soil. The stressed plants showed drastic reduction in net $\mathrm{CO}_{2}$ assimilation and growth variables. There was, however, an increase in performance index $\left(\mathrm{PI}_{\mathrm{ABS}}\right.$ e $\left.\mathrm{PI}_{\text {TOTAL }}\right)$ at different moments of stress between the two cultivars. In general, $R$. communis plants possess mechanisms to protect the electron transport chain during a period of stress, without causing damage and reducing functionality. However, this is not enough to maintain photosynthetic activity owing to the decrease in stomatal conductance and intrinsic carboxylation efficiency, which affects biomass accumulation in stressed plants. In summary, this study found that the 'AL Guarany 2002' was found to be more sensitive to stress than the 'IAC Guarani' was.
\end{abstract}

Key words: Photosynthetic apparatus. Castor beans. JIP Test.

\section{Resumo}

O alagamento do solo é uma condição de estresse que provoca alteração nas relações hídricas e no metabolismo vegetal das culturas, afetando sua produtividade. Para avaliar como esse estresse afeta a fluorescência transiente da clorofila $a$, as trocas gasosas e o crescimento de Ricinus communis, plantas jovens das cultivares 'AL Guarany 2002' e 'IAC Guarani', cultivadas em casa de vegetação, foram submetidas ao alagamento, com manutenção de uma lâmina de água de 2-3 cm acima do solo. As plantas estressadas apresentaram redução drástica da assimilação líquida de $\mathrm{CO}_{2}$ e das variáveis de crescimento, enquanto houve aumento dos índices de performance $\left(\mathrm{PI}_{\mathrm{ABS}}\right.$ e $\mathrm{PI}_{\text {TOTAL }}$ ), porém, em momentos distintos do período de estresse entre as duas cultivares avaliadas. De forma geral, é percebido que as plantas de $R$. communis possuem mecanismos de proteção à cadeia transportadora de elétrons durante o período de estresse, sem causar danos e redução de sua funcionalidade, mas que isto não é o suficiente para

\footnotetext{
${ }^{1}$ Prof. Dr., Biólogo, Departamento de Ciências Biológicas e da Saúde, Universidade Federal do Amapá, UNIFAP, Amapá, Brasil. E-mail: biodavi@gmail.com

2 Prof ${ }^{\mathrm{a}} \mathrm{Dr}^{\mathrm{a}}$, Bióloga, Instituto de Ciências Biológicas, Universidade Federal do Rio Grande, FURG, Campus Carreiros, Rio Grande, Rio Grande do Sul, Brasil. E-mail: emartinazzo@gmail.com

${ }^{3} \mathrm{Dr}^{\mathrm{a}}$ Pesquisadora, Bióloga, Programa de Pós-Graduação em Engenharia de Biossistemas, Universidade Federal Fluminense, UFF, Niterói, Rio de Janeiro, Brasil. E-mail: cristinahuther@yahoo.com.br

${ }^{4}$ Discente, Curso de Mestrado em Fisiologia Vegetal, Eng. Agronômo, Departamento de Botânica, Instituto de Biologia, Universidade Federal de Pelotas, UFPEL, Campus Capão do Leão, Pelotas, RS, Brasil. E-mail: douglasposso@hotmail.com

5 Prof. Dr., Eng ${ }^{\circ}$ Agro $^{\circ}$ Departamento de Botânica, Instituto de Biologia, UFPEL, Campus Capão do Leão, Pelotas, RS, Brasil. E-mail: bacarin@ufpel.edu.br

* Author for correspondence
} 
manutenção da atividade fotossintética, em função da diminuição da condutância estomática e da eficiência intrínseca de carboxilação, afetando o acúmulo de biomassa nas plantas estressadas, sendo a cultivar 'AL Guarany 2002' mais sensível ao estresse quando comparada à 'IAC Guarani'.

Palavras-chave: Aparato fotossintético. Mamona. Teste JIP.

\section{Introduction}

Soil flooding is an abiotic stress that occurs in both natural areas and in agricultural environments, and current prediction models of climate change indicate increased incidence of this kind of event. Accumulation of water in soil compromises agricultural productivity owing to its harmful effect on terrestrial vascular plants (BAILEY-SERRES; VOESENEK, 2008), which causes damage that is proportionate to the intensity and duration of the stress (VISSER et al., 2003).

This stress causes a reduction in oxygen availability in the rhizosphere (PEZESHKI, 2001), disrupting root physiology and reducing the activity of aquaporins (TOURNAIRE-ROUX et al., 2003); this, in turn, leads to a decrease in hydraulic conductance in roots. Thus, dehydration of aerial parts is inevitable, causing oxidative stress, partial closure of the stomata, and photosynthetic capacity reduction (SMETHURST; SHABALA, 2003; PERBONI et al., 2012; KUMAR et al., 2013; MARTINAZZO et al., 2013, LARRÉ et al., 2016).

Castor bean is a non-edible oilseed crop, which has acquired great importance in bioenergy production, thereby reducing dependence on fossil fuels (SMEETS et al., 2007; ZANETTI et al., 2013). Although this species is known for its tolerance to adverse environmental factors such as drought, salinity, and nutrient deficiency (SEVERINO et al., 2012, NOBRE et al., 2013), little is known about its photosynthetic activity in conditions of flooding; this information is necessary for the improvement of this species for the purpose of expanding production in areas that are susceptible to this stress.

The use of techniques such as measuring the chlorophyll $a$ fluorescence transient allows for detailed information to be obtained about the components of the electron transport chain, in a quick and non-destructive manner (STRASSER et al., 2004; TSIMILLI-MICHAEL; STRASSER, 2008). Together with measure of the gas exchange, such analyses allow for important inferences about the sensitivity of photosynthetic activity of plants subjected to flooding (MARTINAZZO et al., 2011). The objective of this study, therefore, was to evaluate the effect of flood stress on the photosynthetic activity and growth of young plants of two castor bean cultivars.

\section{Material and Methods}

\section{Plant material and experimental set-up}

The experimental unit was installed on December 4,2013 , in a greenhouse with an average temperature of $28 \pm 4^{\circ} \mathrm{C}$ and a flux density of photosynthetically active photons of $630 \mu \mathrm{mol}$ photons $\mathrm{m}^{-2} \mathrm{~s}^{-1}$ at the time of measurement. Seeds from two Ricinus comunnis L. cultivars, AL Guarany 2002 and IAC Guarani, were planted in 10-L pots containing a mixture of red latosoil and sand at a ratio of $3: 1$. One week after emergence, thinning was carried out, leaving one plant per pot. The Hoagland and Arnon (1950) nutritive solution was added three times a week, with approximate volumes of $50 \mathrm{~mL} \mathrm{pot}^{-1}$. When the plants had seven to eight leaves (in \pm 30 days), they were randomly divided into two treatments (flooded and control). The plants were subjected to flooding conditions, maintaining a layer of water $2-3 \mathrm{~cm}$ above the ground. The control plants were irrigated daily. Eight plants were used per treatment. Daily assessments comprised measurements of the chlorophyll $a$ fluorescence transient and gas exchange for five days, between 9:00 AM and 11:00 AM. At the end of this period, the growth parameters were assessed. 
Analysis of the chlorophyll a fluorescence transient

Chlorophyll a fluorescence transients were measured with a portable fluorometer HandyPEA (Hanstech, King's Lynn, Norkfolk, UK), using the second uppermost mature leaf. The measurements were performed in the morning on leaves that were accustomed to the dark, for 30 minutes, using clips provided with the equipment. The fluorescence transient was obtained by emitting a pulse of bright light (intensity of $3,000 \mu \mathrm{mol}$ photons $\left.\mathrm{m}^{-2} \mathrm{~s}^{-1}\right)$. The intensity of emitted fluorescence was measured between $50 \mu \mathrm{s}$ and $1 \mathrm{~s}$. From the intensity of fluorescence of chlorophyll $a$, the parameters established by the JIP test (STRASSER; STRASSER, 1995; TSIMILLI-MICHAEL; STRASSER, 2008) were obtained and calculated with product software. The parameters of the JIP test were normalized in relation to their respective controls, where the values of the JIP test parameters are expressed as a fraction relative to the control values as a reference $($ control $=100 \%=1)$.

\section{Gas exchange}

Gas exchange was measured in the second uppermost mature leaf, fully expanded, with a Model LI-6400XT infrared portable $\mathrm{CO}_{2}$ analyser (LI-COR, Inc.; Lincoln, NE, EUA), with measurements taken between 10:00 and 11:00 AM. The conditions of the leaf chamber were controlled so as to obtain a concentration of $380 \mu \mathrm{mol} \mathrm{CO}_{2}$ $\mathrm{mol}^{-1}$ and flux density of photosynthetically active photons of 1,500 $\mu \mathrm{mol}$ photons $\mathrm{m}^{-2} \mathrm{~s}^{-1}$. The following variables were measured: net assimilation rate of $\mathrm{CO}_{2}(A)$; stomatal conductance $\left(g_{\mathrm{s}}\right)$; transpiration rate $(E)$; and internal $\mathrm{CO}_{2}$ concentration $\left(C_{\mathrm{i}}\right)$. The net assimilation rate of $\mathrm{CO}_{2}$ and the transpiration rate provided by the equipment are calculated using the von Caemmerer and Farquhar model (1981). From the data obtained, we calculated the intrinsic efficiency of carboxylation $\left(A / C_{\mathrm{i}}\right)$ and the instantaneous efficiency of water use $(A / E)$.

\section{Plant growth}

At the end of the period of stress, measurements were taken for (i) plant height; (ii) stem diameter; (iii) number of leaves; (iv) total leaf area; (v) specific leaf area; (vi) dry weight of leaves; and (vii) dry weight of the stem.

The plant height and stem diameter were measured from the area where the roots meet the base of the plant, with the aid of a millimeter ruler and digital calliper, respectively. The number of leaves was determined by simple counting of all the leaves per plant. The total leaf area of green leaves was measured by using a LI-3100 model leaf area measurement tool (LI-COR Inc., Lincoln, NE, EUA). The stems and leaves were separately packed in paper bags and dried in a circulating air oven at $65^{\circ} \mathrm{C}$ for three days to obtain dry mass. Specific leaf area was obtained using the ratio of total leaf area to dry mass of leaves.

\section{Statistical analysis}

The experimental design was completely randomized, with eight plants used per treatment, and one reading per plant. The variables of gas exchange and growth were subjected to variance analysis $(p \leq 0.05)$, and significant differences between the treatment means were determined by Student's $t$-test.

\section{Results}

\section{Fluorescence transient: JIP Test}

For all treatments, the emission of fast kinetics chlorophyll fluorescence showed characteristic transient polyphase OJIP (STRASSER et al., 2004) when fluorescence intensities were plotted on a logarithmic scale with time (data not shown).

As for JIP test parameters related to the specific flux through the centre of active reaction, it was observed that the dissipation flux $\left(\mathrm{DI}_{0} / \mathrm{RC}\right)$ had a small decrease in stressed plants, whereas there was 
an increase of the electron transport flux $\left(\mathrm{ET}_{0} / \mathrm{RC}\right)$ on the first day of stress in 'IAC Guarani' (Figure 1B) and on the fourth day for 'AL Guarany 2002' (Figure 1A).

For quantum yield values, little change was observed in the quantum yield of primary photochemistry $\left(\phi_{\mathrm{Po}}\right)$, whereas there was an increase in quantum yield of electron transport $\left(\phi_{\mathrm{Eo}}\right)$ starting on the first and fourth day of stress in 'IAC Guarani' and 'AL Guarany 2002', respectively. The quantum yield of reduction of the final acceptors of photosystem I (PSI) $\left(\phi_{\mathrm{Ro}}\right)$ increased beginning on the fourth day for 'AL Guarany 2002' and on the third and fourth day for 'IAC Guarani'.

In plants subjected to flood conditions, it was verified that the probability that an exciton captured by the PSII reaction centre moves an electron in the electron transport chain $\left(\Psi_{\mathrm{Eo}}\right)$ increased starting on the first day for 'AL Guarany 2002' and on the fourth day for 'IAC Guarani', with more pronounced results noted for the 'AL Guarany 2002'. The probability that an electron can move from the reduced intersystem electron acceptors (intermediate carriers between PSII and PSI plastoquinone, cytochrome $\mathrm{b}_{6} \mathrm{f}$, and plastocyanin) to the PSI end electron acceptors $\left(\delta_{\mathrm{Ro}}\right)$ increased only in 'IAC Guarani' starting on the first day, thereafter decreasing during the trial period, and approaching the level of control plants on the fifth day of stress.

The performance index involved with the potential for energy conservation for photons absorbed by PSII to reduce the intersystem acceptors
$\left(\mathrm{PI}_{\mathrm{ABS}}\right)$ (STRASSER et al., 2004) and the total performance index, involved with the conservation of energy absorbed by PSII for the reduction of final PSI acceptors ( $\left.\mathrm{PI}_{\mathrm{TOTAL}}\right)$, a product of $\mathrm{PI}_{\mathrm{ABS}}$ and $\delta_{\mathrm{Ro}}$ (TSIMILLI-MICHAEL; STRASSER, 2008) of the plants under flood conditions, showed an increase when compared to control plants (Figure 1A). In 'AL Guarany 2002', this increase was observed on the fourth and fifth day of stress, whereas in 'IAC Guarani', it occurred on the first day, with gradual reduction throughout the period of stress, and returning to the level of control plants at the end of the trial period. Still, there were greater $\mathrm{PI}_{\text {TOTAL }}$ values measured in the control than those of the $\mathrm{PI}_{\mathrm{ABS}}$ in 'IAC Guarani' due to the increase in $\delta_{\mathrm{Ro}}$ observed in this cultivar.

\section{Gas exchange}

It was observed that, in relation to the first day of stress, there was a decrease of the values of gas exchange of the control plants on the second and third day of stress, in both cultivars (Figure 2). This was probably due to the high temperatures recorded in the period (maximum temperature between $29^{\circ} \mathrm{C}$ and $36^{\circ} \mathrm{C}$ ).

Gas exchange was affected in plants subjected to flooding (Figure 2). The net assimilation rate $(A)$ was reduced under flood conditions in both cultivars, differing significantly from of the control starting on the second and third day of stress in 'IAC Guarani' and 'AL Guarany 2002', respectively (Figure 2A e B). 
Figure 1. JIP test parameters provided by the equipment, calculated from the chlorophyll a fluorescence, plant Ricinus communis, cultivars AL Guarany 2002 (A) and IAC Guarani (B), $1^{\text {st }}(\mathbf{\square}), 2^{\text {nd }}(\bullet), 4^{\text {th }}(\square)$ and $5^{\text {th }}(\circ)$ days subject to flooding. The values were normalized using the reference control.

A
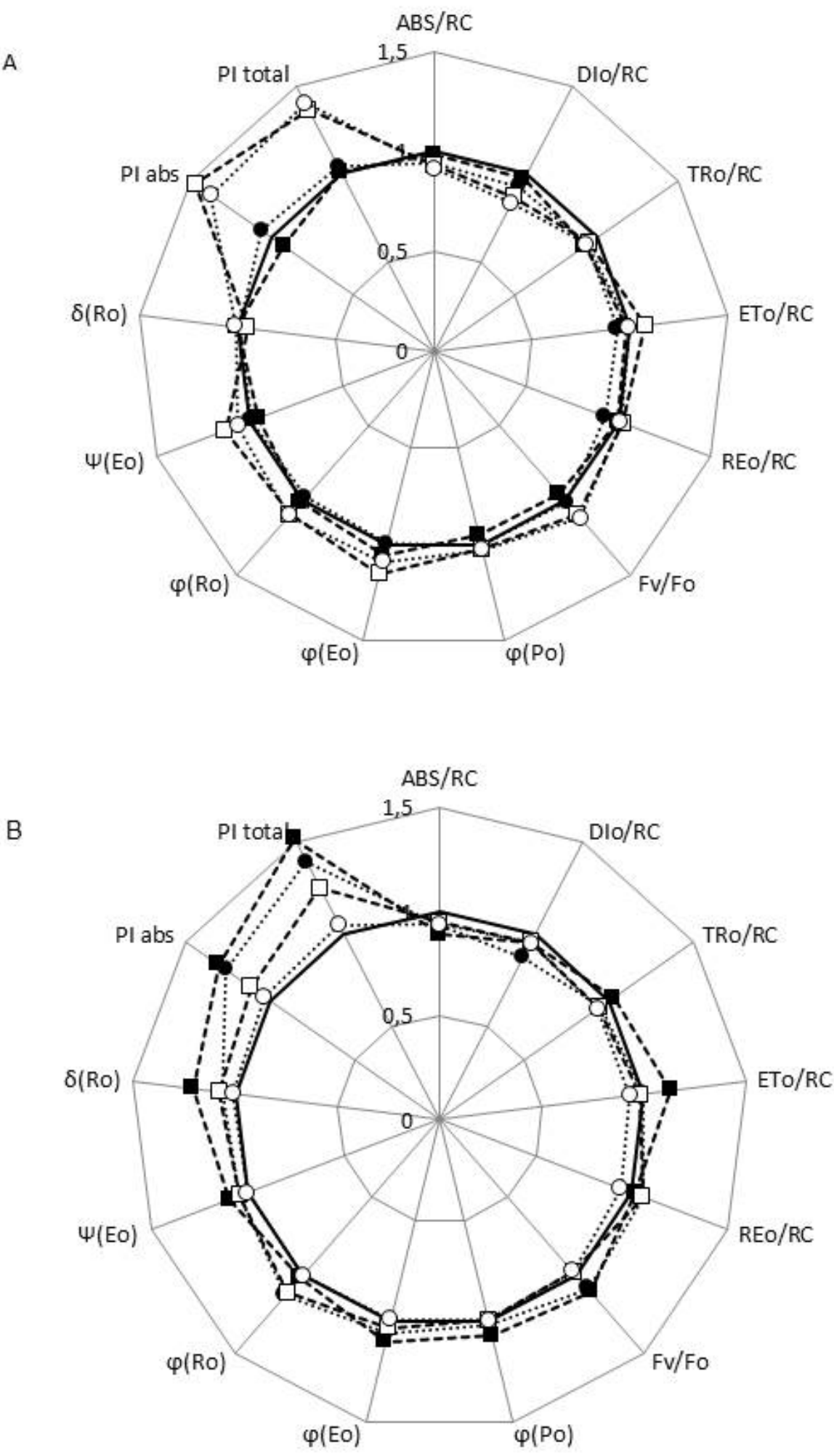
Figure 2. Parameters of gas exchange of leaves of Ricinus communis, 'AL Guarany 2002' (A, C, E, G) e 'IAC Guarani' $(\mathrm{B}, \mathrm{D}, \mathrm{F}, \mathrm{H})$, under control $(\circ)$ and flooding $(\bullet)$. Net assimilation rate $(A)$, stomatal conductance $\left(g_{\mathrm{s}}\right)$, transpiration rate $(E)$, internal concentration of $\mathrm{CO}_{2}\left(C_{\mathrm{i}}\right)$. Bars indicate standard error of the mean. *Indicate significant differences between treatments by the Student $t$ test $(p \leq 0.05)$. ns, with no significant difference.
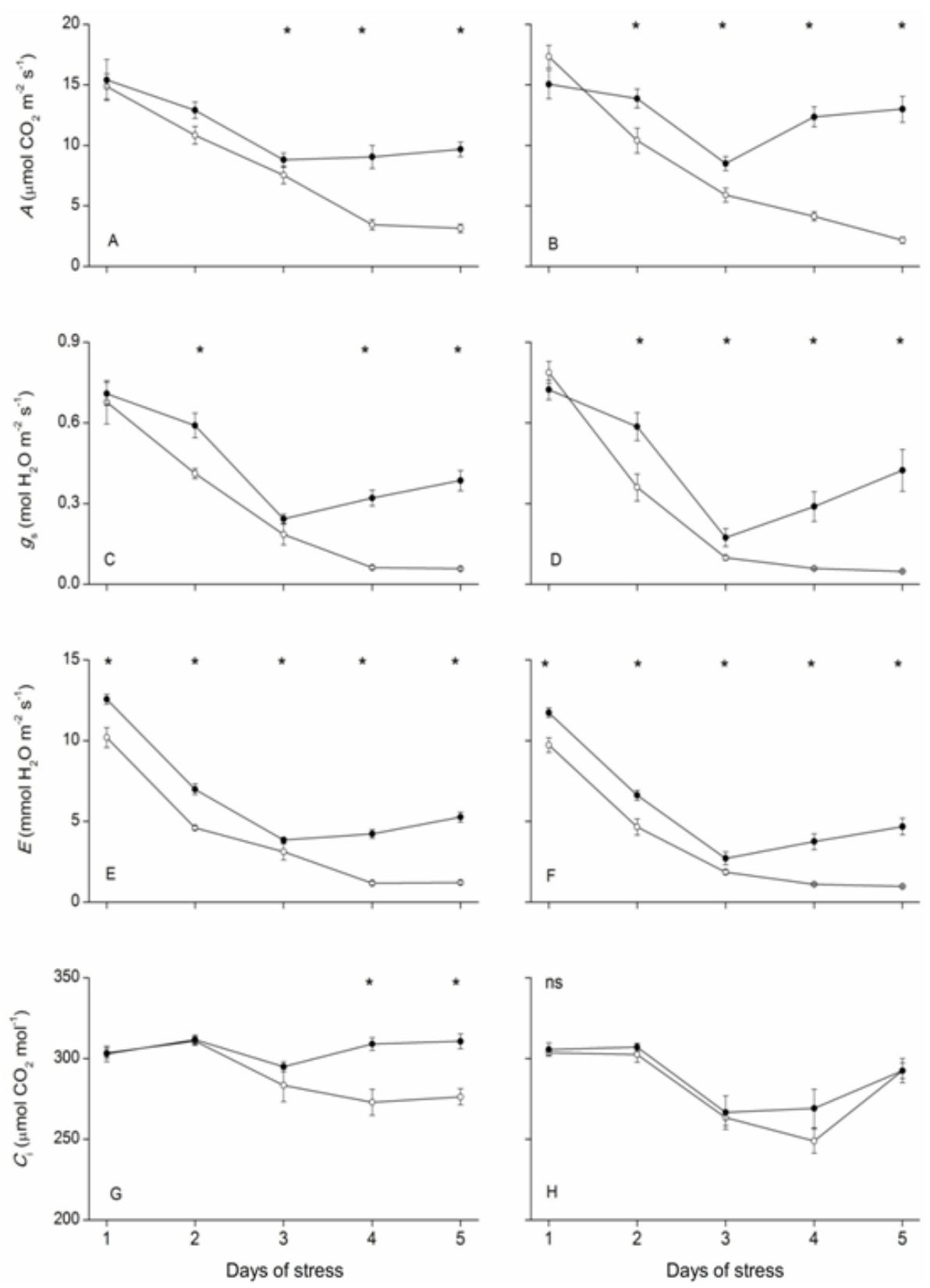

Stomatal conductance $\left(g_{\mathrm{s}}\right)$ was also affected by soil flooding, causing differences from the control starting on the second day of stress in both cultivars (Figures $2 \mathrm{C}$ e D). On the third day of stress, no significant different was observed between the 'AL Guarany 2002' control plants and under stress.
This reflected the transpiration rate $(E)$ values, with a significant decrease in this variable occurring from the beginning of stress (Figures 2E e F), with extremely low values on the fourth and fifth day of stress. 
The internal concentration of $\mathrm{CO}_{2}\left(C_{\mathrm{i}}\right)$ decreased significantly in 'AL Guarany 2002' on the fourth day of stress when compared to the control, whereas the plants under flood conditions and the control plants did not differ for this variable in 'IAC Guarani' (Figures $2 \mathrm{G} \mathrm{e} \mathrm{H}$ ).

Carboxylation efficiency $\left(A / C_{\mathrm{i}}\right)$ showed a constant decrease over the course of the stress conditions, with significant differences observed from the second day for 'IAC Guarani' and from the third day for 'AL Guarany 2002' (Table 1). This decrease was due to the relative maintenance of $C_{\mathrm{i}}$ values, whereas there was concomitant decrease of $A$. The intrinsic efficiency of water use $(A / E)$ increased significantly on the fourth and fifth day of stress in 'AL Guarany 2002', whereas the increase was noted only on the fourth day in 'IAC Guarani' (Table 2).

Table 1. Values of intrinsic carboxylation efficiency $\left(A / C_{\mathrm{i}}\right.$, expressed in $\left.\mu \mathrm{mol} \mathrm{CO}_{2} \mathrm{~m}^{-2} \mathrm{~s}^{-1} \mathrm{~Pa}^{-1}\right)$ in castor bean plants subjected to flooding.

\begin{tabular}{|c|c|c|c|c|}
\hline \multicolumn{5}{|c|}{ Intrinsic carboxylation efficiency $\left(\mu \mathrm{mol} \mathrm{CO} \mathrm{Cm}^{-2} \mathrm{~s}^{-1} \mathrm{~Pa}^{-1}\right)$} \\
\hline \multirow{2}{*}{ Days of stress } & \multicolumn{2}{|c|}{ AL Guarany 2002} & \multicolumn{2}{|c|}{ IAC Guarani } \\
\hline & Control & Flooding & Control & Flooding \\
\hline 1 & $0.511 \pm 0.0064$ & $0.487 \pm 0.0035$ & $0.493 \pm 0.044$ & $0.569 \pm 0.033$ \\
\hline 2 & $0.412 \pm 0.0023$ & $0.348 \pm 0.0026$ & $0.449 \pm 0.027$ & $0.343 \pm 0.036^{*}$ \\
\hline 3 & $0.297 \pm 0.0020$ & $0.236 \pm 0.0018^{*}$ & $0.315 \pm 0.012$ & $0.224 \pm 0.025^{*}$ \\
\hline 4 & $0.292 \pm 0.0033$ & $0.127 \pm 0.0019^{*}$ & $0.458 \pm 0.028$ & $0.169 \pm 0.020^{*}$ \\
\hline 5 & $0.310 \pm 0.0023$ & $0.114 \pm 0.0014^{*}$ & $0.441 \pm 0.036$ & $0.074 \pm 0.011 *$ \\
\hline
\end{tabular}

* Indicates significant difference between the means within each cultivar, the $\mathrm{T}$ test at $5 \%$ significance. Mean values \pm standard error of the mean $(n=8)$.

Table 2. Values of instantaneous efficiency of water use $\left(A / E\right.$, expressed in $\mu$ mol $\left.\mathrm{CO}_{2} \mathrm{mmol}^{-1} \mathrm{H}_{2} \mathrm{O}\right)$ in castor bean plants subjected to flooding.

\begin{tabular}{|c|c|c|c|c|}
\hline \multirow{3}{*}{ Days of stress } & \multicolumn{4}{|c|}{ Instantaneous efficiency of water use $\left(\mu \mathrm{mol} \mathrm{CO}{ }_{2} \mathrm{mmol}^{-1} \mathrm{H}_{2} \mathrm{O}\right)$} \\
\hline & \multicolumn{2}{|c|}{ AL Guarany 2002} & \multicolumn{2}{|c|}{ IAC Guarani } \\
\hline & Control & Flooding & Control & Flooding \\
\hline 1 & $1.22 \pm 0.11$ & $1.46 \pm 0.06$ & $1.28 \pm 0.09$ & $1.80 \pm 0.10$ \\
\hline 2 & $1.86 \pm 0.09$ & $2.34 \pm 0.11$ & $2.11 \pm 0.11$ & $2.29 \pm 0.16$ \\
\hline 3 & $2.29 \pm 0.09$ & $2.59 \pm 0.24$ & $3.34 \pm 0.29$ & $3.15 \pm 0.18$ \\
\hline 4 & $2.12 \pm 0.14$ & $2.97 \pm 0.25^{*}$ & $3.52 \pm 0.35$ & $3.74 \pm 0.25^{*}$ \\
\hline 5 & $1.86 \pm 0.14$ & $2.55 \pm 0.14^{*}$ & $2.86 \pm 0.21$ & $2.22 \pm 0.18$ \\
\hline
\end{tabular}

* Indicates significant difference between the means within each cultivar, the $\mathrm{T}$ test at $5 \%$ significance. Mean values \pm standard error of the mean média $(\mathrm{n}=8)$.

\section{Plant growth}

Stress due to flooding resulted in less growth in the aerial parts of both cultivars (Table 3). A drastic reduction was noted in the number of leaves, in the dry mass of leaves, and in the total leaf area, with decreases of $27 \%, 29 \%$, and $36 \%$ in 'AL Guarany 2002 ' and $37 \%, 43 \%$, and $52 \%$ in 'IAC Guarani'. However, an increase was observed in specific leaf mass in these plants (13\% in 'AL Guarany 2002' and
$19 \%$ in 'IAC Guarani'), which may be the result of lower turgor pressure, which decreases cell growth (ELSE et al., 2001). The increase in stem diameter above the area where the roots meet the stem $(27 \%$ in 'AL Guarany 2002' and 37\% in 'IAC Guarani') occurred without significant change in the dry mass of the stem, which may indicate the formation of aerenchyma on these plants. 
Table 3. Growth parameters in castor bean plants subjected to flooding.

\begin{tabular}{|c|c|c|c|}
\hline Paramater & Cultivar & Control & Flooding \\
\hline \multirow{2}{*}{$\begin{array}{l}\text { Plant height } \\
\text { (cm) }\end{array}$} & AL Guarany 2002 & $21.21 \pm 0.75$ & $19.29 \pm 1.12$ \\
\hline & IAC Guarani & $20.23 \pm 1.10$ & $18.45 \pm 0.54$ \\
\hline \multirow{2}{*}{$\begin{array}{l}\text { Stem diameter } \\
(\mathrm{mm})\end{array}$} & AL Guarany 2002 & $7.53 \pm 0.26$ & $9.60 \pm 0.29^{* * *}$ \\
\hline & IAC Guarani & $7.19 \pm 0.13$ & $9.87 \pm 0.27^{* * *}$ \\
\hline \multirow[t]{2}{*}{ Number of leaves } & AL Guarany 2002 & $4.63 \pm 0.26$ & $3.38 \pm 0.18^{* *}$ \\
\hline & IAC Guarani & $5.38 \pm 0.42$ & $3.38 \pm 0.18^{* *}$ \\
\hline \multirow{2}{*}{$\begin{array}{l}\text { Total leaf area } \\
\left(\mathrm{cm}^{2} \text { plant }{ }^{-1}\right)\end{array}$} & AL Guarany 2002 & $479.39 \pm 21.27$ & $305.33 \pm 17.85^{* * *}$ \\
\hline & IAC Guarani & $559.00 \pm 40.23$ & $269.16 \pm 18.73^{* * *}$ \\
\hline \multirow{2}{*}{$\begin{array}{l}\text { Leaf dry mass } \\
\quad\left(\mathrm{g}_{\text {plant }}{ }^{-1}\right)\end{array}$} & AL Guarany 2002 & $1.47 \pm 0.07$ & $1.05 \pm 0.07^{* * *}$ \\
\hline & IAC Guarani & $1.95 \pm 0.14$ & $1.11 \pm 0.07^{* * *}$ \\
\hline \multirow{2}{*}{$\begin{array}{c}\text { Stem dry mass } \\
\left(\mathrm{g}_{\text {plant }}{ }^{-1}\right)\end{array}$} & AL Guarany 2002 & $1.11 \pm 0.05$ & $1.24 \pm 0.06$ \\
\hline & IAC Guarani & $1.33 \pm 0.07$ & $1.28 \pm 0.03$ \\
\hline \multirow{2}{*}{$\begin{array}{l}\text { Specific leaf area } \\
\left(\mathrm{mg} \mathrm{cm}^{-2}\right)\end{array}$} & AL Guarany 2002 & $3.06 \pm 0.14$ & $3.45 \pm 0.34^{*}$ \\
\hline & IAC Guarani & $3.50 \pm 0.16$ & $4.18 \pm 0.36^{* * *}$ \\
\hline
\end{tabular}

\section{Discussion}

By reducing the oxygen content in the rhizosphere, flooding leads to reduced respiratory rates and therefore reduced functionality of the roots, affecting hydric relationships, nutrient absorption, and hormonal balance (KREUZWIESER et al., 2004; SAIRAM et al., 2008; VIDOZ et al., 2010; VOESENEK; SASIDHARAN, 2013). This way, there are severe changes in the physiology and morphology of plants subjected to this stress (COLMER; VOESENEK, 2009).

Although there is no difference in height measurements and dry weight of the stem between the plants subjected to flooding and the control plants of both cultivars, there was an observed increase in stem diameter. This is an indication of the formation of spongy tissue and an adaptive response frequently observed in plants under flood conditions (YAMAUCHI et al., 2013; GONÇALVES et al., 2013; LANZA et al., 2013; LARRÉ et al., 2013) that allows for better diffusion of gases in the waterlogged plant (JACKSON; COLMER, 2005; AHMED et al., 2012).

The reduction in dry weight of leaves was the result of morphological changes such as the decrease in the number of leaves and leaf area, similar to that found in Theobroma cacao (REHEM et al., 2009) and Pyrus boissieriana (PARAD et al., 2013). This response appears to be mediated by ethylene, once the flooding stimulates the synthesis of this hormone (VOESENEK; SASIDHARAN, 2013; VAN VEEN et al., 2014; SHANG et al., 2014), which signals senescence and leaf abscission (IRFAN et al., 2010). On the other hand, specific leaf mass was greater in flooded plants than in the control plants, due to a reduction in the surface area available for transpiration, protecting against dehydration (POORTER et al., 2009).

Gas exchange was extremely affected by flood conditions. It decreased over the period of stress, with a more intense impact on IAC Guarani plants. The reduction in $g_{\mathrm{s}}$ is another efficient mechanism against water loss through transpiration, with the same mechanism also observed in Solanum lycopersicum (ELSE et al., 2009) and Vigna radiata (ARAKI et al., 2014). This is due to reduction in the hydraulic conductivity of the xylem in flooded plants (HOLBROOK; ZWIENIECKI, 2003), which negatively affects the ability to replace the water content that is transpired, thus reducing the water potential and triggering signalling that leads to 
reduced stomatal opening (ELSE et al., 2001, 2006). The increase in specific leaf mass, together with a decrease in conductance, becomes an important strategy for reducing water loss by transpiration, thus preventing irreversible wilting of leaves when subjected to light (DAT et al., 2004; IRFAN et al., 2010).

Despite being able to maintain water content in leaves, the reduction in $g_{\mathrm{s}}$ in flooded plants leads to increased stomatal resistance to the diffusion of $\mathrm{CO}_{2}$ (MCDOWELL, 2011). This undermines carbon assimilation, and we found a strong positive correlation between $g_{\mathrm{s}}$ and $A$ in the plants of both castor bean cultivars. This behaviour is commonly observed in plants under these conditions (GARCÍA $\square$ SÁNCHEZ et al., 2007; LI et al., 2007; OLIVEIRA; JOLY, 2010).

Another factor to be considered is the decrease in carboxylation efficiency shown in these plants, which indicates mechanisms of non-stomatal photosynthesis limitation. The decrease in carboxylation efficiency may occur due to lower carboxylase RuBisCO activity in plants under flood conditions (YORDANOVA; POPOVA, 2007). In addition, the accumulation of photoassimilates in the leaves caused by the reduction in the phloem sap flow in flooded castor bean plants (PEUKE et al., 2014) can result in the feedback inhibition of photosynthesis (STITT, 1986).

Even with the decrease in gas exchange, stress due to flooding stimulated activity of the electron transport chain in the chloroplast, as observed by data on the fluorescence transient. The increased performance of the light reactions $\left(\mathrm{F}_{\mathrm{V}} / \mathrm{F}_{0}\right)$ and electron transport $\left(\phi_{\mathrm{E}_{\mathrm{o}}}\right.$ e $\left.\Psi_{\mathrm{Eo}}\right)$ in stressed plants contributes to more efficient use of energy absorbed, which results in reducing the dissipation of absorbed energy, as indicated by lower $\mathrm{DI}_{0} / \mathrm{RC}$ values.

In addition to these modifications, 'IAC Guarani' showed increased PSI activity, with higher values of $\delta_{\mathrm{Ro}}$, which may be related to the increase in cyclic flow of electrons around the PSI, an important adaptation strategy in stress conditions favouring the formation of the proton gradient and the synthesis of ATP, and avoiding excessive formation of NADPH, and consequently, the formation of reactive types of oxygen and photoinhibition (HUANG et al., 2012).

The evaluation of the performance index $\left(\mathrm{PI}_{\mathrm{ABS}}\right)$, which expresses the capacity for conservation of absorbed energy (STRASSER et al., 2004), and has been shown to be sensitive to small changes experienced by plants subjected to various environmental stresses, allows for the inference that plants of both cultivars, when subjected to flooding, showed an increase in potential conservation capacity of absorbed energy. This response was not observed in other plants as Erythrina crista-galli (LARRÉ et al., 2013) in hybrid Prunus dulcis x P. persica or in $P$. salicina (MARTINAZZO et al., 2011, 2013), where there was a drastic decrease in $\mathrm{PI}_{\mathrm{ABS}}$ when plants were subjected to flooding. Furthermore, the total performance index $\left(\mathrm{PI}_{\text {TOTAL }}\right)$ which incorporates the performance of decreased reactions of the final electron acceptors and, therefore, reflects the overall action of the electron transport chain (TSIMILLIMICHAEL; STRASSER, 2008), obtained a greater result as compared to the control than $\mathrm{PI}_{\mathrm{ABS}}$ in 'IAC Guarani'.

Since there was a decrease in carbon assimilation, it is likely that increased activity of the photosynthetic apparatus may be related to increased photorespiration, which is common in plants with C3 metabolism experiencing water deficit (VOSS et al., 2013) and water-water cycle, that functions as a utilization strategy to reduce ATP surplus power (ASADA, 1999; RIZHSKY et al., 2003), balancing the redox state of the photosynthetic tissue and the production of reactive oxygen species (GILL; TUTEJA, 2010). This allows for maintenance of the flow of electrons on the transport chain, reducing the excitation pressure on photosystems (TAKAHASHI; BADGER, 2011).

It is important to stress that these changes occurred at different times in the cultivars that were assessed. While flooded 'AL Guarany 2002' showed alteration 
of activity in the electron transport chain only at the end of the trial period (on the fourth and fifth day of stress), 'IAC Guarani' were more sensitive, showing these responses from the beginning of the period of stress, with subsequent reduction over time, demonstrating that the adaptation strategy is not maintained over the long-term.

\section{Conclusions}

During the period of stress due to soil flooding, there was no loss of function of the photosynthetic apparatus of the two castor bean cultivar studies, but an increase in the different performance index was observed.

Stress due to soil flooding causes a decrease in photosynthetic activity in young castor bean plants as a result of decreased carboxylation efficiency. Moreover, the accumulation of biomass is reduced in castor bean plants subjected to flooding, due to reduction in leaf area. Finally, the stress response due to flooding is dependent on the genotype, and the 'AL Guarany 2002' cultivar is less sensitive to this stress than the 'IAC Guarani' cultivar.

\section{Acknowledgement}

CNPq, CAPES, FINEP and Ministry of Science and Technology for financial support, and Embrapa Clima Temperado for supplying the seeds used in this research.

\section{References}

AHMED, F.; RAFII, M. Y.; ISMAIL, M. R.; JURAIMI, A. S.; RAHIM, H. A.; ASFALIZA, R.; LATIF, M. A. Waterlogging tolerance of crops: breeding, mechanism of tolerance, molecular approaches, and future prospects. BioMed Research International, Cairo, v. 2013, n. 1, p. 1-10, 2012.

ARAKI, T.; OO, T. T.; KUBOTA, F. Effects of flooding treatments on photosynthetic activity of different greengram (Vigna radiata (L.) Wilczek) cultivars. Environmental Control in Biology, Tóquio, v. 52, n. 1, p. 1-5, 2014.

ASADA, K. The water-water cycle in chloroplasts: scavenging of active oxygens and dissipation of excess photons. Annual Review of Plant Biology, Palo Alto, v. 50, n. 1, p. 601-639, 1999.

BAILEY-SERRES, J.; VOESENEK, L. A. C. J. Flooding stress: acclimations and genetic diversity. Annual Review of Plant Biology, Palo Alto, v. 59, n. 1, p. 313-339, 2008.

COLMER, T. D.; VOESENEK, L. A. C. J. Flooding tolerance: suites of plant traits in variable environments. Functional Plant Biology, Clayton South, v. 36, n. 8, p. 665-681, 2009.

DAT, J. F.; CAPELLI, N.; FOLZER, H.; BOURGEADE, P.; BADOT, P. M. Sensing and signalling during plant flooding. Plant Physiology and Biochemistry, Paris, v. 42, n. 4, p. 273-282, 2004.

ELSE, M. A.; COUPLAND, D.; DUTTON, L.; JACKSON, M. B. Decreased root hydraulic conductivity reduces leaf water potential, initiates stomatal closure and slows leaf expansion in flooded plants of castor oil (Ricinus communis) despite diminished delivery of ABA from the roots to shoots in xylem sap. Physiologia Plantarum, Lund, v. 111, n. 1, p. 46-54, 2001.

ELSE, M. A.; JANOWIAK, F.; ATKINSON, C. J.; JACKSON, M. B. Root signals and stomatal closure in relation to photosynthesis, chlorophyll $a$ fluorescence and adventitious rooting of flooded tomato plants. Annals of Botany, Exeter, v. 103, n. 2, p. 313-323, 2009.

ELSE, M. A.; TIEKSTRA, A. E.; CROKER, S. J.; DAVIES, W. J.; JACKSON, M. B. Stomatal closure in flooded tomato plants involves abscisic acid and a chemically unidentified anti-transpirant in xylem sap. Plant Physiology, Rockville, v. 112, n. 1, p. 239-247, 2006.

GARCÍA-SÁNCHEZ, F.; SYVERTSEN, J.; GIMENO, V.; BOTÍA, P.; PEREZ-PEREZ, J. G. Responses to flooding and drought stress by two citrus rootstock seedlings with different water-use efficiency. Physiologia Plantarum, Lund, v. 130, n. 4, p. 532-542, 2007.

GILL, S. S.; TUTEJA, N. Reactive oxygen species and antioxidant machinery in abiotic stress tolerance in crop plants. Plant Physiology and Biochemistry, Paris, v. 48, n. 12, p. 909-930, 2010.

GONÇALVES, J. F.; MELO, E. G.; FERREIRA, M. J.; SILVA, C. E. M.; GOMES, I. B. Crescimento, partição de biomassa e fotossíntese em plantas jovens de Genipa spruceana submetidas ao alagamento. Cerne, Lavras, v. 19, n. 1, p. 193-200, 2013.

HOAGLAND, D. R.; ARNON, D. I. The water culture 
method for growing plants without soil. Berkeley: California Agricultural Experiment Station, 1950. 32 p.

HOLBROOK, N. M.; ZWIENIECKI, M. A. Plant biology: water gate. Nature, Londres, v. 425, n. 6956, p. 361-361, 2003.

HUANG, W.; YANG, S. J.; ZHANG, S. B.; ZHANG, J. L.; CAO, K. F. Cyclic electron flow plays an important role in photoprotection for the resurrection plant Paraboea rufescens under drought stress. Planta, Bonn, v. 235, n. 4, p. 819-828, 2012.

IRFAN, M.; HAYAT, S.; HAYAT, Q.; AFROZ, S.; AHMAD, A. Physiological and biochemical changes in plants under waterlogging. Protoplasma, Karlsruhe, v. 241, n. 1-4, p. 3-17, 2010.

JACKSON, M. B.; COLMER, T. D. Response and adaptation by plants to flooding stress. Annals of Botany, Exeter, v. 96, n. 4, p. 501-505, 2005.

KREUZWIESER, J.; PAPADOPOULOU, E.; RENNENBERG, H. Interaction of flooding with carbon metabolism of forest trees. Plant Biology, Freiburg, v. 6, n. 3, p. 299-306, 2004.

KUMAR, P.; PAL, M.; JOSHI, R.; SAIRAM, R. K. Yield, growth and physiological responses of mung bean [Vigna radiata (L.) Wilczek] genotypes to waterlogging at vegetative stage. Physiology and Molecular Biology of Plants, Lucknow, v. 19, n. 2, p. 209-220, 2013.

LANZA, L. N. M.; ROSSI, S. C.; SODEK, L. Nitrogen fertilization benefits soybean under flooding conditions. Bragantia, Campinas, v. 72, n. 1, p. 2-9, 2013.

LARRÉ, C. F.; FERNANDO, J. A.; MARINI, P.; BACARIN, M. A.; PETERS, J. A. Growth and chlorophyll a fluorescence in Erythrina crista-galli L. plants under flooding conditions. Acta Physiologiae Plantarum, Cracóvia, v. 35, n. 5, p. 1463-1471, 2013.

LARRÉ, C. F.; MORAES, C. L.; BORELLA, J.; AMARANTE, L. do; DEUNER, S.; PETERS, J. A. Atividade antioxidante e metabolismo fermentativo em plantas de Erythrina crista-galli sob alagamento. Semina: Ciências Agrárias, v. 37, n. 2, p. 567-580, 2016.

LI, M.; YANG, D.; LI, W. Leaf gas exchange characteristics and chlorophyll fluorescence of three wetland plants in response to long-term soil flooding. Photosynthetica, Praga, v. 45, n. 2, p. 222-228, 2007.

MARTINAZZO, E. G.; PERBONI, A. T.; FARIAS, M. E.; BIANCHI, V. J.; BACARIN, M. A. Photosynthetic activity in the rootstock of hybrid peach trees submitted to water restriction and flooding. Brazilian Journal of Plant Physiology, Campos do Goytacazes, v. 23, n. 3, p. 231-236, 2011.
MARTINAZZO, E. G.; PERBONI, A. T.; OLIVEIRA, P. V.; BIANCHI, V. J.; BACARIN, M. A. Photosynthetic activity in japanese plum under water deficit and flooding. Ciência Rural, Santa Maria, v. 43, n. 1, p. 35-41, 2013.

MCDOWELL, N. G. Mechanisms linking drought, hydraulics, carbon metabolism, and vegetation mortality. Plant Physiology, Rockville, v. 155, n. 3, p. 1051-1059, 2011.

NOBRE, R. G.; LIMA, G. S. de; GHEYI, H. R.; ANJOS SOARES, L. A. dos; SILVA, S. S. da; SILVA, A. O. da; SILVA LOURENÇO, G. da. Crescimento e produção da mamoneira cultivada sob diferentes níveis de salinidade da água de irrigação e doses de nitrogênio. Semina: Ciências Agrárias, v. 34, n. 3, p. 961-974, 2013.

OLIVEIRA, V. C.; JOLY, C. A. Flooding tolerance of Calophyllum brasiliense Camb. (Clusiaceae): morphological, physiological and growth responses. Trees, Vancouver, v. 24, n. 1, p. 185-193, 2010.

PARAD, G. A.; ZARAFSHAR, M.; STRIKER, G. G.; SATTARIAN, A. Some physiological and morphological responses of Pyrus boissieriana to flooding. Trees, Vancouver, v. 27, n. 5, p. 1387-1393, 2013.

PERBONI, A. T.; CASSOL, D.; SILVA, F. S. P.; SILVA, D. M.; BACARIN, M. A. Chlorophyll a fluorescence study revealing effects of flooding in canola hybrids. Biologia, Bratislava, v. 67, n. 2, p. 338-346, 2012.

PEUKE, A. D.; GESSLER, A.; TRUMBORE, S.; WINDT, C. W.; HOMAN, N.; GERKEMA, E.; VAN AS, H. Phloem flow and sugar transport in Ricinus communis L. is inhibited under anoxic conditions of shoot or roots. Plant, Cell and Environment, Logan, v. 38, n. 3, p. 433447, 2014.

PEZESHKI, S. R. Wetland plant responses to soil flooding. Environmental and Experimental Botany, Paris, v. 46, n. 3, p. 299-312, 2001.

POORTER, H.; NIINEMETS, Ü.; POORTER, L.; WRIGHT, I. J.; VILLAR, R. Causes and consequences of variation in leaf mass per area (LMA): a meta-analysis. New Phytologist, Lancaster, v. 182, n. 3, p. 565-588, 2009.

REHEM, B. C.; ALMEIDA, A. F.; MIELKE, M. S.; GOMES, F. P. Efeitos do alagamento do substrato no crescimento e na composição química de genótipos clonais de Theobroma cacao L. Revista Brasileira de Fruticultura, Jaboticabal, v. 31, n. 3, p. 805-815, 2009.

RIZHSKY, L.; LIANG, H.; MITTLER, R. The waterwater cycle is essential for chloroplast protection in the absence of stress. Journal of Biological Chemistry, Rockville, v. 278, n. 40, p. 38921-38925, 2003. 
SAIRAM, R. K.; KUMUTHA, D.; EZHILMATHI, K.; DESHMUKH, P. S.; SRIVASTAVA, G. C. Physiology and biochemistry of waterlogging tolerance in plants. Biologia Plantarum, Praga, v. 52, n. 3, p. 401-412, 2008.

SEVERINO, L. S.; AULD, D. L.; BALDANZI, M.; CÂNDIDO, M. J. D.; CHEN, G.; CROSBY, W.; TAN, D.; HE, X.; LAKSHMAMMA, P.; LAVANYA, C.; MACHADO, O. L. T.; MIELKE, T.; MILANI, M.; MILlER, T. D.; MORRIS, J. B.; MORSE, S. A.; NAVAS, A. A.; SOARES, D. J.; SOFIATTI, V.; WANG, M. L.; ZANOTTO, M. D.; ZIELER, H. A review on the challenges for increased production of castor. Agronomy Journal, Madison, v. 104, n. 4, p. 853-880, 2012.

SHANG, J.; SONG, P.; MA, B.; QI, X.; ZENG, Q.; XIANG, Z.; HE, N. Identification of the mulberry genes involved in ethylene biosynthesis and signaling pathways and the expression of MaERF-B2-1 and MaERF-B2-2 in the response to flooding stress. Functional \& Integrative Genomics, Istambul, v. 14, n. 4, p. 767-777, 2014.

SMEETS, E. M.; FAAIJ, A. P.; LEWANDOWSKI, I. M.; TURKENBURG, W. C. A bottom-up assessment and review of global bio-energy potentials to 2050. Progress in Energy and Combustion Science, Stanford, v. 33, n. 1, p. 56-106, 2007.

SMETHURST, C. F.; SHABALA, S. Screening methods for waterlogging tolerance in lucerne: comparative analysis of waterlogging effects on chlorophyll fluorescence, photosynthesis, biomass and chlorophyll content. Functional Plant Biology, Clayton South, v. 30, n. 3, p. 335-343, 2003.

STITT, M. Limitation of photosynthesis by carbon metabolism I. Evidence for excess electron transport capacity in leaves carrying out photosynthesis in saturating light and $\mathrm{CO}_{2}$. Plant Physiology, Rockville, v. 81, n. 4, p. 1115-1122, 1986.

STRASSER, B. J; STRASSER, R. J. Measuring fast fluorescence transients to address environmental questions: the JIP-test. In: MATHIS, P. Photosynthesis: from light to biosphere. Montpellier: Springer, 1995. p. 977-980.

STRASSER, R. J.; TSIMILLI-MICHAEL, M.; SRIVASTAVA, A. Analysis of the chorophyll a fluorescence transient. In: PAPAGEORGIOU, G. C.; GOVINDJEE. Chlorophyll a fluorescence: a signature of photosynthesis. Dordrecht: Spring, 2004. p. 321-362.

TAKAHASHI, S.; BADGER, M. R. Photoprotection in plants: a new light on photosystem II damage. Trends in Plant Science, Cambridge, v. 16, n. 1, p. 53-60, 2011.

TOURNAIRE-ROUX, C.; SUTKA, M.; JAVOT, H.; GOUT, E.; GERBEAU, P.; LUU, D. T.; MAUREL, C.
Cytosolic $\mathrm{pH}$ regulates root water transport during anoxic stress through gating of aquaporins. Nature, Londres, v. 425, n. 6956, p. 393-397, 2003.

TSIMILLI-MICHAEL, M.; STRASSER, R. J. In vivo assessment of plants vitality: applications in detecting and evaluating the impact of Mycorrhization on host plants. In: VARMA, A.; ROCK, B. Mycorrhiza. $3^{\text {th }}$ ed. Uttar Pradesh: Springer, 2008. p. 679-703.

VAN VEEN, H.; AKMAN, M.; JAMAR, D. C.; VREUGDENHIL, D.; KOOIKER, M.; TIENDEREN, P.; SASIDHARAN, R. Group VII Ethylene Response Factor diversification and regulation in four species from flood-prone environments. Plant, Cell \& Environment, Logan, v. 37, n. 10, p. 2421-2432, 2014.

VIDOZ, M. L.; LORETI, E.; MENSUALI, A.; ALPI, A.; PERATA, P. Hormonal interplay during adventitious root formation in flooded tomato plants. The Plant Journal, Londres, v. 63, n. 4, p. 551-562, 2010.

VISSER, E. J. W.; VOESENEK, L. A. C. J.; VARTAPETIAN, B. B.; JACKSON, M. B. Flooding and plant growth. Annals of Botany, Exeter, v. 91, n. 2, p. 107-109, 2003.

VOESENEK, L. A. C. J.; SASIDHARAN, R. Ethyleneand oxygen signalling-drive plant survival during flooding. Plant Biology, Freiburg, v. 15, n. 3, p. 426-435, 2013.

VON CAEMMERER, S.; FARQUHAR, G. D. Some relationships between the biochemistry of photosynthesis and the gas exchange of leaves. Planta, Bonn, v. 153, n. 4, p. 376-387, 1981.

VOSS, I.; SUNIL, B.; SCHEIBE, R.; RAGHAVENDRA, A. S. Emerging concept for the role of photorespiration as an important part of abiotic stress response. Plant Biology, Freiburg, v. 15, n. 4, p. 713-722, 2013.

YAMAUCHI, T.; SHIMAMURA, S.; NAKAZONO, M.; MOCHIZUKI, T. Aerenchyma formation in crop species: a review. Field Crops Research, Bonn, v. 152, n. 1, p. 8-16, 2013.

YORDANOVA, R. Y.; POPOVA, L. P. Flooding-induced changes in photosynthesis and oxidative status in maize plants. Acta Physiologiae Plantarum, Cracóvia, v. 29, n. 6, p. 535-541, 2007.

ZANETTI, F.; MONTI, A.; BERTI, M. T. Challenges and opportunities for new industrial oilseed crops in EU27: A review. Industrial Crops and Products, St Martin d'Heres, v. 50, n. 1, p. 580-595, 2013. 